\begin{tabular}{|l|l|l|l|}
\hline Eiszeitalter u. Gegenwart & 35 & $7-8$ & Hannover 1985 \\
\hline
\end{tabular}

\title{
Shorelines Formed During Quaternary Marine Regression: Examples and Inferences from Southern Scotland (Progress report)
}

\author{
[Küstenlinien, die sich im Verlauf einer quartären \\ marinen Regression gebildet haben: Beispiele \\ und Schlußfolgerungen aus dem südlichen Schottland \\ (Fortschrittsbericht)]
}

William Graham Jardine \& William Edgar Boyd *)

Interpretation, marine regression, shorelines, morphodynamics, geomorphological feature, marine terraces, cliff, sedimentary successions, transgression, Holocene (9000 years B. P.). Southern Scotland (Forth Valley), North Sea

As elsewhere, the main method of identifying the position of a former (regressive) Quaternary marine shoreline in S Scotland is by the recognition of either a physical or a vegetational boundary. Commonly a physical boundary is a geomorphological feature. For example, in the Forth valley west of Stirling the boundaries between concealed (regressive) terraces, termed the High, Main and Low 'Buried Beaches', are small cliffs (Sissons 1966: 20-24; 1967, 175-178). Similarly, at several locations along the northern seaboard of the Solway Firth frequently a distinct cliff, ranging up to c. $2 \mathrm{~m}$ in height, occurs at the boundary between 'carse' deposits of the main Holocene marine incursion and the adjacent lower area, the 'merse' (JARDINE 1980: 44). In both the Forth and Solway areas the simple, normal 'stepped' situation is replaced locally by a more complex situation: e. g. the Low Buried Beach of the Forth valley comprises a veneer of later sediments resting on a bench that was cut into deposits of the Main Buried Beach during marine regression c. 9000 years bp; at Redkirk Point on the Solway Firth, phases of erosive activity by the receding or stationary sea were interrupted by depositional activity so that 'cliffs' and 'benches' are covered partly by marine deposits (JARDINE 1980: figs. $12 \mathrm{~A}$ and $12 \mathrm{~B}$ ).

The abrupt break (represented by a cliff) in the Holocene regression on the $\mathrm{N}$ coast of the Solway Firth contrasts with the last part of the preceding (major) transgression

*) Addresses of the authors: Dr. W. G. JARdine, Dr. W. E. Boyd, Department of Geology, University of Glasgow, Glasgow G 12 8QQ, United Kingdom. 
(e. g. in the vicinity of Newbie Cottages; JARDINE 1980: fig. 12 C), in which there is sedimentary evidence of oscillation between minor transgressive and minor regressive episodes. Does the cliff indicate a change of relative sea level (associated with isostatic uplift) whereas the interstratified sediments indicate (minor) transgressive-regressive effects produced by local factors rather than by changes of sea level?

The sequence at Newbie Cottages provides a link between the use of physical and vegetational criteria in the recognition of the positions of former marine shorelines. At that location, the position of the shoreline is not marked by a recognisable landform. There is, however, sedimentary evidence of the shoreline position, the deposits immediately seawards of the former shoreline comprising, in upward vertical succession: organic detritus, inorganic silts and clays, peat.

Such a sequence is typical of a number of former shoreline locations in N Germany, Denmark, N England and S Scotland. At certain coastal locations in NW Europe, however, a vertical sequence that consists entirely of organic deposits is to be found. At such locations, the position of the regressive shoreline may require to be established ' . . . on the assumption that replacement of a saltmarsh plant community by terrestrial taxa indicates inception of a marine regression ...' (JARDINE 1981: 298). The situation is compounded further where the only record of a marine event that is preserved in a cored profile is a gap in the vegetational sequence. BOYD encountered this problem at Linwood Moss, in the vicinity of Glasgow. He constructed a model to illustrate various possibilities in the development of sedimentary successions during a marine transgressive and regressive event in a coastal area of organic accumulation (BOYD 1982: 67-71; figs. 8.2 and 8.3). Within the context of marine regression, BoYD distinguished two major categories: regression caused by 1 o $\mathrm{c}$ a 1 progradation; regression on a regional scale (commonly as the result of change of sea level).

Evidence from vegetational sequences may allow successive (and datable) regressive shoreline positions to be established; geomorphological evidence may be less useful in this respect.

\section{References}

BoyD, W. E. (1982): The stratigraphy and chronology of Late Quaternary raised coastal deposits in Renfrewshire and Ayrshire, western Scotland. - Ph. D. thesis, University of Glasgow: Vol. I, 285 pp.; Vol. II, 113 pp., Glasgow. - [Unpubl.].

JARDINE, W. G. (1980): Holocene raised coastal sediments and former shorelines of Dumfriesshire and eastern Galloway. - Trans. J. Proc. Dumfries. Galloway Nat. Hist. Antiq. Soc., 55: 1-59; Dumfries.

- (1981): Holocene shorelines in Britain: recent studies. - Geol. Mijnbouw, 60: 297-304; Leiden.

Sissons, J. B. (1966): Relative sea-level changes between 10,300 and 8,300 B. P. in part of the Carse of Stirling. - Trans. Inst. Br. Geogr., 39: 19-29; London.

- (1967): The evolution of Scotland's scenery. - 259 pp.; Edinburgh. 